\title{
Lesbian Writing and Authorship in the Polish Literary Tradition: How to Define the Non-defined?
}

\author{
Katarzyna Lisowska \\ University of Wrocław \\ Faculty of Philology \\ katarzyna.lisowska@uwr.edu.pl
}

Received 12 July 2021; accepted 19 September 2021; published 28 December 2021.

\begin{abstract}
The aim of this article is to analyse the conceptualisation of lesbian writing and authorship in the Polish literary tradition. The paper discusses various contexts, definitions, applications and uses of these concepts in Polish literary studies. In the article, the texts of such authors as, for instance, Inga Iwasiów, Marta Tomczok, Ewa Chudoba, Błażej Warkocki and Renata Lis are referred to. As a consequence, the specific heterogeneity of Polish discussion about lesbian writing and authorship is presented. These phenomena are situated in the broader context of Western conceptualizations of the analysed subject.
\end{abstract}

Keywords: lesbian writing/literature; lesbian authorship; queer theory; love between women; female homoeroticism

\section{Introduction}

This article addresses the question whether and how the terms "lesbian writing" and "lesbian literature" function in Polish literary studies. It also attempts to examine whether there are any definitions or theories of this phenomenon therein, or whether it is comprehended rather intuitively. In addition, the issue of lesbian authorship, inseparably connected with the notions mentioned above, is referred to. In what follows, I present an overview of Polish theoretical texts directly addressing the question of "lesbian literature/authorship," as well as some etymological comments on the words "(a) lesbian" and "lesbianism." The next part of the paper discusses how these notions function in the selected articles published in Poland. I also pay attention to the context which has shaped the status of these phenomena in Polish culture, as well as to some characteristic motifs which recur in various texts referring to the subject 
of lesbian writing in Poland. Finally, I draw some conclusions regarding the possibility - or impossibility - of applying the presented terms and, broadly speaking, concepts, to the Polish material. ${ }^{1}$

Although "lesbian writing" and "lesbian literature" have not been the subject of comprehensive theoretical reflection in Poland, what has been written on the subject quite directly presents its specificity. The basic sources which should be mentioned here are the fragments of Krystyna Kłosińska's study Feministyczna krytyka literacka [Feminist literary criticism] (the chapter "Lesbijska feministyczna krytyka literacka" [Lesbian feminist literary criticism]), 2010, pp. 613-631 ${ }^{2}$ and the relevant entries in Encyklopedia gender. Pteć $w$ kulturze $e^{3}$ [The gender encyclopedia. Gender in culture] (mainly "Literatura lesbijska" [Lesbian literature] by Katarzyna Nadana-Sokołowska, 2014a, pp. 270-274, but also "Literatura homoseksualna (męska)" [Homosexual (male) literature] by Błażej Warkocki, 2014, pp. 263-265, as well as "Lesbianizm" [Lesbianism] by Agnieszka Gajewska, 2014, pp. 256-2594). ${ }^{5}$ Due to the complexity of the subject, in what follows, I have selected texts providing an overview of the issues which can be considered when studying the functioning of the concepts of lesbian writing and authorship in the Polish context. However, neither the list of topics nor the choice of sources $^{6}$ are complete and it is my hope that these questions will be further discussed in subsequent publications. ${ }^{7}$

\footnotetext{
${ }^{1}$ Although some of the quoted critical texts mention foreign literature as well, in order to maintain the coherence of the paper, in what follows, I focus mostly on Polish writings and do not present a detailed analysis of the local reception of non-Polish works which depict female homoeroticism

${ }^{2}$ Unless otherwise stated, all translations are my own.

${ }^{3}$ Henceforth: Encyklopedia gender.

${ }^{4}$ Gajewska's entry does not represent literary studies in a strict sense, but, having been published in the aforementioned encyclopedia, it functions as an important context of these studies.

${ }^{5}$ Apart from that, the encyclopedia also features Katarzyna Nadana-Sokołowska's entry "Związki kobiet” [Relationships between women], discussing various forms of female couples and friendships - not all of which can be classified as lesbian (2014b, pp. 596-599).

${ }^{6}$ Another important source is the monumental volume Dezorientacje. Antologia polskiej literatury queer [Confusions. The anthology of the Polish queer literature], edited by Alessandro Amenta, Tomasz Kaliściak and Błażej Warkocki (2021), which I cite mostly in the final paragraph of this paper, since the perspective offered by the authors corresponds with my concluding remarks. In addition, most parts of this article had been written before the anthology was published. As such, this text presents the state of research before the book by Amenta, Kaliściak and Warkocki opened a completely new chapter in the studies of non-heterosexuality in Polish literature.

${ }^{7}$ Note: there are two authors to whom in the text I refer by two names each - Marta Cuber/Tomczok and Izabela Filipiak/Morska. This is because these authors have changed their names since the publication of the texts that I cite in this paper. I have decided to mark this change by addressing the authors by both names. I retain the original surname under which the articles were published only in the case of bibliographical descriptions of Cuber/Tomczok's and Morska/Filipiak's studies.
} 


\section{Definitions}

In her monograph, Krystyna Kłosińska presents the most important topics discussed by Western lesbian literary criticism, including its key issues, namely the objects of these studies lesbian writing, as well as lesbian authorship (2010, pp. 616-624). The scholar refers to different concepts that aimed at defining the literature in question. Consequently, she provides the reader with a vast, often inconsistent (given the variety of approaches) picture of this debate. In addition, she mentions other topics related to the issue of lesbian literature, such as the problem of tradition and literary canon (Kłosińska, 2010, pp. 621-622, 626-630) as well as the role of the author's biography and the hypothesis of a lesbian reader, considered to be a recipient with a specific interpretational perspective and skills (Kłosińska, 2010, pp. 619, 625). This chapter of Kłosińska's study is particularly important because it can serve as a summary of the theoretical basis for further analyses related to Polish texts; at the same time, however, the book, which focuses on various aspects of Western feminist literary criticism in general, does not refer to the local context.

The second relevant publication is the aforementioned Encyklopedia gender. In the entry devoted to lesbian literature, Katarzyna Nadana-Sokołowska presents the functioning of the notion, with a brief overview of its characteristics and with reference to the Polish context (2014a, pp. 270-274). As the author notices, a number of definitions were based on the question of lesbian poetics (2014a, p. 272). ${ }^{8}$ In addition, as Nadana-Sokłowska and Kłosińska note, the answers provided and the notions used by lesbian criticism tend to be deconstructed by scholars in the field of queer studies (Nadana-Sokołowska 2014, p. 272; Kłosińska 2010, pp. 630631). It is also worth emphasising that lesbian literature and male homosexual literature are described in Encyklopedia gender separately, which implies that the distinction between these two types of writing is important. These differences have also their Polish specificity, often evoked in literary studies and critical texts; this is discussed in the further part of this paper. What is more, it should be noted that while Warkocki differentiates between male homosexual literature and gay literature in his entry on that subject (2014, pp. 263-264), at the same time providing some remarks on the history of the word "gej" (a gay man) in Polish (and noting that the term started to be used in Poland in the middle of the 1980s; 2014, p. 264), no analogous distinctions (female homosexual literature vs. lesbian literature) and explanations can be found in the entry devoted to lesbian literature. Nevertheless, the lack of etymological reflection is compensated for with some remarks formulated by Agnieszka Gajewska in the part "Lesbianizm" (2014, p. 256), where the author, having briefly described the etymology of the term "lesbianizm" (lesbianism), refers to Bonnet's and other authors' concepts in order to problematize the meaning and usage of the words in question $(2014$, p. 256$)$ and deprive them of their ostensibly unambiguous status. The scholar also stresses that for centuries, words such as "lesbianism" and "sapphism" functioned as insults and there is no evidence that women

8 The author refers to Kłosińska’s observations. 
used them as self-description (2014, p. 256). ${ }^{9}$ However, she does not specifically refer to their history in Polish.

The etymological analyses are important, since, as Marie-Jo Bonnet demonstrated with reference to the French material (1997, pp. 43-62), the words "(a) lesbian" and "lesbianism" are not politically or otherwise neutral and it would be productive to sketch their history in Polish culture. Such etymological reflection is present in the study of Ewa Chudoba, ${ }^{10}$ who devotes a whole section to the cultural distinctiveness of lesbian motifs in literature (not only in Polish; 2012, pp. 33-39), as well as to the history of the word "lesbian," stressing that neither of the most widespread terms which describe love between women was coined by women themselves (33-34). Although the author does not discuss the functioning of the term "lesbian" in Polish either, she emphasizes that since the second half of the $19^{\text {th }}$ century, in English speaking countries (and probably in other Western cultures), this word has been most commonly used to describe women's homoerotic relationships (Chudoba, 2012, pp. 34-35, 37-39). In the context of the Polish language, linguistic sources may prove to be helpful. ${ }^{11}$ It seems that the word "lesbian," being of a Greek origin, has functioned in Polish longer than "gay," although it was not considered an affirmative name (cf. Gajewska, 2014, p. 256). Both terms are mentioned in Stownik seksualizmów polskich [Dictionary of Polish sex words] (the former in the forms of "lesba"/"lesbijka"), which comprises the material spanning the time from the $15^{\text {th }}$ century until the middle of the $20^{\text {th }}$ century (Lewinson, 1999, pp. IX, 61, 116). Jagoda Rodzoch-Malek (2012) suggests that the adjective "lesbian" has functioned in Polish since the interwar period and the noun "a lesbian" was first registered in the Dictionary of Polish Language [Stownik języka polskiego] edited by Witold Doroszewski and published in the 1950s and $1960 \mathrm{~s}^{12}$ (Rodzoch-Malek, 2012, pp. 104-105; I owe the reference to Rodzoch-Malek to Nowak, 2020). ${ }^{13}$ It is believed that in English the word in question, both as a noun and as an adjective,

\footnotetext{
${ }^{9}$ As Mariola Bieńko rightly notes on the basis of the entries collected in Słownik seksualizmów polskich [Dictionary of Polish sex words] (cf. Lewinson, 1999), female homoeroticism, not only in the Polish language, tends to be characterized by the lack of linguistic expression (2019, p. 87).

${ }^{10}$ The scholar also refers to Bonnet's analyses of the functioning of the word "a lesbian" in French (Chudoba, 2012 , pp. 35, 38). What is also important, Chudoba is reluctant to use the terms "a lesbian" or "lesbianism" anachronistically (cf. 2012, pp. 37, 259). At the same time, however, it seems that sometimes, similarly to Warkocki (see the further part of the paper), the author uses the term as a strategic label, both with reference to the contemporary works (Chudoba, 2012, pp. 274-278) and to older ones (pp. 261-263).

${ }^{11}$ Here, except for the sources cited in the main text, the pioneer book of Tomasz Łukasz Nowak (2020), which has initiated Polish lavender linguistics, has to be mentioned (34). The author focuses on the gay (masculine homosexual) sociolect in Poland; at the same time, he formulates some general observations on non-heteronormativity in Polish and provides a reader with an overview of more general analyses related to this phenomenon in Poland (Nowak, 2020, pp. 30-43). As it is impossible and unnecessary to develop this subject here, it is enough to refer to the article by Andrzej S. Dyszak (2014) - also cited by Nowak - which presents the variety of words used in Polish, registered in general and slang dictionaries to describe non-heterosexual women (cf. especially pp. 58-59).

${ }^{12}$ Cf. Doroszewski (1962).

${ }^{13}$ This word is not registered in the earlier dictionaries, originally published either in the $19^{\text {th }}$ century (cf. Linde, 1808), or in the first decades of the $20^{\text {th }}$ century (cf. Brückner, 1927; Karłowicz, Kryński \& Niedźwiedzki, 1952 [1902]). However, in the seventh volume of the latter, we can find the definition of tribadism which pictures
} 
has been used since the $17^{\text {th }}$ century (Donoghue, 1993, as cited in Norton, 2002, The 'Lesbian' Section, para. 5; I owe this reference to Śmieja, 2015, p. 57).

In addition, it seems clear that, historically, the words "(a) lesbian" and "lesbianism" were not the only ones to be used in the writings published in Poland with reference to female homoeroticism. For instance, Łukasz Nastulczyk and Piotr Oczko enumerate such terms as tribades, frictices and subigatrices (Nastulczyk \& Oczko, 2012, p. 154; the first of them, derived from Greek, was thoroughly analysed by Bonnet - cf. 1997, pp. 43-62). Moreover, what further complicates the functioning of the words "(a) lesbian" and "lesbianism" in Poland is that, as the scholars mention, lesbiari was a word used to denote oral sex (Nastulczyk \& Oczko, 2012, p. 155 , footnote 298 ) and, as a consequence, it did not necessarily point to women's homosexuality (probably not without reason, the authors define lesbiari as "fellatio," which further suggests that it was not bound to refer to sexual practices between women; Nastulczyk \& Oczko, 2012, p. 155, here also footnote 298). ${ }^{14}$ These remarks are important because they expose the complexity of the words which describe love between women in Polish. ${ }^{15}$

\section{The Discourse of Literary Criticism}

In the next part of this paper, I present the functioning of the notions of lesbian writing and authorship in Polish academic and critical sources. A brief overview of texts ${ }^{16}$ which refer to the problem of literary and cultural depictions of love between women allows for distinguishing a few typically mentioned nodal points of the history of this issue. It is often stressed that up until the $19^{\text {th }}$ century these motifs were virtually absent in the cultural discourse in Poland (Nastulczyk \& Oczko, 2012, pp. 38-40). Then came the era of romantic friendships (Nadana-

this phenomenon as a female desire counter to nature (Karłowicz, Kryński \& Niedźwiedzki, 1952 [1919], p. 133).

${ }^{14}$ Bonnet also cites the Greek verb lesbiazein, which meant not only having sex in a way considered to be typical of women from Lesbos, but also simply “to lick" (1997, p. 50).

${ }^{15}$ It is also worth noticing that texts which discuss the functioning of the local LGBT movements suggest the moments when the word "(a) lesbian" was already in use in Poland as a self-descriptive, affirmative term. For instance, Robert Biedroń mentions the group LL - Lesbian Lambda (the original name), founded by Polish activists in 1990, as well as the portal "Polish Lesbians Site" (the original name), launched in 1996 (Biedroń, 2010, pp. 89, 92). Moreover, Jerzy Krzyszpień, in the article about the terminology proposed for the local discourse about non-heterosexuality, uses these words extensively (Krzyszpien, 2010, pp. 142-144). Therefore, it could be concluded that in Poland, similarly to Western countries (cf. Krzyszpień, 2010, p. 141), at some point, despite its former negative connotations, the term "(a) lesbian" became related to the emancipatory movement, which, however, occurred in Poland later than in the regions mentioned above. For more about the history of the language of non-heterosexuality in Poland, see the volume of "InterAlia" (2019/14), which presents some results of the project CRUSEV - "Cruising the 70s. Unearthing Pre-HIV/AIDS Queer Sexual Cultures."

${ }^{16}$ I confine myself to the texts published within the frame of professional (in Stanley Fish's understanding of this word - cf. Fish, 1999) discourse. I do not diminish the role of other modes of reading; however, since they seem to express different expectations and patterns of interpretation, I am not able to discuss them in this paper (see also Sobolczyk, 2015, pp. 130-139). 
Sokołowska, 2014a, pp. 270; 2014b, pp. 597-599; ${ }^{17}$ Iwasiów, 2001, pp. 437-438) ${ }^{18}$, which tends to be associated with Narcyza Żmichowska's novels Poganka [Pagan] i Biała róża [White rose] (Walczewska, 2000, pp. 148-150; Lis, 2017, pp. 60-66; Amenta, Kaliściak $\&$ Warkocki, 2021, pp. 47-50). The $19^{\text {th }}$ century and the beginning of the $20^{\text {th }}$ century can be characterized by the strengthening of the role of relationships between women, supposed to provide a substitute for the heterosexual marriage (Walczewska, 2000, pp. 144-154; NadanaSokołowska, 2014b, pp. 597-599). However, the nature of these relationships is unknown to us, partly due to the fact that usually they were not depicted in any cultural texts by women themselves (Walczewska, 2000, pp. 147-148, 151-153). ${ }^{19}$ The next stage is the interwar period and the vague traces of female homoeroticism which some scholars tend to find in a small group of works written by women (a commonly given example is Aniela Gruszecka's novel Przygoda w nieznanym kraju [The adventure in an unknown country]) (Cuber, 2003; Iwasiów 2001, p. 437; Kraskowska, 2003, pp. 101-125; Amenta, Kaliściak \& Warkocki, 2021, p. 52). Afterwards, a long break in the academic and critical narration about lesbian motifs in Polish culture can be noticed (see also Iwasiów, 2001, p. 438). Such reflections are absent in the period of the People's Republic of Poland. The next traces of love between women in Polish literature are found in the last decade of the previous century and at the beginning of the $21^{\text {st }}$ century, when texts were published, including poetry and prose, which expressed female homoeroticism more openly (Iwasiów, 2001, pp. 438-451; Cuber, 2003; Walczewska, 2000, pp. 153-154; Warkocki, 2007, pp. 33-36, 41-42); here Ewa Schilling's and Izabela Filipiak's/Morska's works are often cited as an example.

It seems that on the level of critical discourse, "the Polish gay literature complex," which results from the already mentioned weak position of love between women in Polish culture, can be observed..$^{20}$ Indeed, it is often stressed that while love between men is represented by a number of works, mostly fiction, lesbian writing is still not so prominent in Polish literature (cf.

\footnotetext{
${ }^{17}$ The author refers also to the studies upon the situation in Western countries.

${ }^{18}$ Iwasiów's remarks are also inspired by the comments formulated by Grażyna Borkowska in her studies: 1996; 1998.

19 Since it is impossible to determine the nature of the discussed couples, the author uses two terms to describe them - either "lesbian relationships" ("związki lesbijskie"; Walczewska, 2000, pp. 144, 146, 153), or “women's friendships" ("przyjaźnie kobiece”; pp. 144, 146), without ascribing any of the presented examples to either one or the other term. However, it seems that lesbianism is the major phenomenon to which the analysed issues are supposed to belong - indeed, the scholar suggests including the aforementioned relationships in the history of lesbianism (Walczewska, 2000, p. 146).

At the same time, Izabela Morska/Filipiak, when writing about the last decades of the $19^{\text {th }}$ century in Poland, stresses the conservative, heteronormative character of the Polish women's movement of this period (Filipiak, 2006, pp. 61-68, 86-89) and, in her analysis of the life and biography of Maria Komornicka / Piotr Włast, the scholar exposes the fears and negative connotations related to female homosexuality in the $19^{\text {th }}$ and at the beginning of the $20^{\text {th }}$ century (pp. 297-305, 314-317). This is not to claim that, as a consequence, the relationships described by Walczewska automatically lose their subversive potential, especially since, as I have already mentioned, we do not know their nature. However, Morska/Filipiak's remarks should make us even more careful about applying the words "lesbian" and "lesbianism" to this epoch in Poland.

${ }^{20}$ It is also worth mentioning that the issue of female homoeroticism has been long discussed in Polish feminist studies (see a brief overview of the studies provided by Inga Iwasiów, 2001, pp. 436-440). Interestingly, Urszula
} 
Iwasiów, 2008, pp. 71-74; Darska, 2006, pp. 191, 204; Lis, 2018a, para. 6). The ambivalent presence of male homoerotic desire in the literary tradition in Poland can be attributed to its wide (not only in the local context) cultural background and textual strategies (which constitute the so-called "poetics of inexpressible desire," as defined by German Ritz - cf. e.g. 1998), which enabled authors to code and hide representations of non-heteronormative love between men in their texts and, as a consequence, to place their works in the centre of the literary canon (Ritz, 2002b, pp. 60-61; Śmieja, 2010, p. 15; Warkocki, 2007, pp. 187, 191, 194-195). ${ }^{21}$ In addition, emancipatory writing which openly depicted masculine homosexuality produced more significant and widely discussed publications, with Michał Witkowski's Lubiewo [Lovetown] usually cited in the first place (Iwasiów, 2008, pp. 73-74; Darska, 2006, pp. 191, 204). In contrast, the symbolic basis of depictions of female relationships, whose importance - at least in European and American culture - tended to be diminished (Mizielińska, 2006, pp. 101109; Bonnet, 1997), is significantly less developed. However, this does not mean that it does not exist. ${ }^{22}$ Although some traces of female homoeroticism have been found in earlier literature (Gowing, 2009, pp. 125-126; Nadana-Sokołowska, 2014a, p. 271), it was not until the beginning of the $20^{\text {th }}$ century and the interwar period that the literature depicting relationships between women began to flourish in the Western countries (the so called Sapphic Modernism; Kłosińska, 2010, p. 631; Nadana-Sokołowska, 2014a, p. 271; Faderman, 1995, pp. 49-59; Jay, 1995, pp. 72-83; Warkocki, 2007, p. 138). Nevertheless, no analogous phenomenon has been observed in Polish literature (despite the aforementioned vague traces found especially in the prose of Aniela Gruszecka), in which, as I have already mentioned, the motifs in question gained visibility as late as in the last decade of the previous century. It is, therefore, characteristic that in the Polish context, the beginnings of the theory of lesbian writing and lesbian writing itself were parallel; in some cases, the theory, based on Western sources quickly appropriated after 1989, might have even preceded literature (in contrast to Western countries, where scholars could already refer to some specific group of works).

At this point, a short digression regarding the modernist context of literature depicting homosexual relations may be useful. It seems that in the context of Polish literature, two models (or registers) of writing can be observed: the modernist one and the style rooted in popular culture (the remarks formulated in this passage are inspired by the observations presented in Cuber,

Śmietana argues that lesbian writing is better recognized than the gay one, because the former is related to feminist literary studies with a longer tradition in Poland than the studies on gender and, I will add, sexuality itself (2007, p. 215). Although the scholar is right to refer to this context, it seems that - mainly because of its more significant development - gay literature has, nonetheless, been more broadly discussed within academic and critical discourses.

${ }^{21}$ Chudoba mentions - as one of the characteristics of the literary representations of both male and female homoeroticism - the wide intertextual relations between various works which refer to this subject (2012). These dialogues, as the scholar argues, have enabled a number of authors to code and hide the non-heterosexual desire in the text (cf. e.g. Chudoba, 2012, pp. 40, 283). However, it seems that in the context of the Polish material, this observation refers mostly to literature depicting male homosexuality (obviously, some exceptions can be named - see Chudoba, 2012, pp. 258-273).

${ }^{22}$ According to Inga Iwasiów, since female homoeroticism is not present in the majority of the classic literary works, its literary tradition is more private. At the same time, lesbian literature has to confront two significant obstacles, i.e. masculine and heteropatriarchal domination (Iwasiów, 2004, pp. 108-109). I owe the reference to this article to the (anonymous) reviewer. 
2012, pp. 73-80). Referring to German Ritz (2002a; 1998, pp. 131-143), one may argue that Polish male homoerotic (but not necessarily gay ${ }^{23}$ ) works belong to the modernist culture. In contrast, many contemporary texts which problematize the non-heterosexual experience relate to the codes of popular culture (Cuber, 2012, p. 73; Darska, 2006, pp. 192-193). These remarks refer mainly to the texts which code male homosexuality. At the same time, it remains an open question whether Polish literature which depicts love between women has its modernist version. Renata Lis answers this question negatively (2018a, para. 5), in contrast to Inga Iwasiów, who points out the modernist roots of the writing of Filipiak/Morska (Iwasiów, 2008, p. 73). It is possible that both authors are right - Lis admits that there are some dispersed minor texts (2018a, para. 5) and Filipiak/Morska's writing certainly provides part of them. However, this might be not enough to distinguish some separate modernist tradition.

In order to analyse the functioning of the terms lesbian writing/literature and lesbian authorship in Polish literary studies more carefully, I refer to selected articles which apply these notions in different ways or discuss the issues related to them. I start with the essay of Marta Cuber/Tomczok entitled "Les-silent story," in which the author aims at presenting Polish lesbian writing, which is referred to with various expressions, such as: "Polish lesbian prose" ("polska proza lesbijska"), "(Polish) lesbian literature" (“(polska) literatura lesbijska”), "the literature/prose/novels of lesbians" ("literatura/proza/powieści lesbijek"), or, more generally, "texts with lesbian motifs" ("teksty z wątkami lesbijskimi”) (Cuber, 2003). The author sketches some lines of the development of this type of writing in Poland, ${ }^{24}$ focusing on the already mentioned novels of Żmichowska (Poganka) and Gruszecka (Przygoda w nieznanym kraju), later moving on to Filipiak/Morska and to Ewa Schilling, as well as to Monika Mostowik and the online publications of Urszula Raczyńska (Cuber, 2003). Although Cuber/Tomczok does not clearly define the enumerated terms, she ascribes certain features to them, such as the expression of the experience of lesbianism ("doświadczenie lesbizmu"), which is believed to allow for the introduction of new values to literature (Cuber, 2003, section: "Chałwa $z$ literatura," para. 2), ${ }^{25}$ as well as some aspects of the poetics of the texts which refer to female homoeroticism (Cuber, 2003, section: "Kartki z Odessy," para. 2). ${ }^{26}$ The latter remarks, however, are limited to the works of contemporary authors (those who made theirs debuts in the 1990s or at the beginning of the $21^{\text {st }}$ century). At the same time Cuber/Tomczok rejects the necessity of defining lesbian prose and poetry as a distinct type of literature, arguing that texts with lesbian motifs do not require a specific type of reading and should only be evaluated on the basis on their assumed literary value (Cuber, 2003, section: "Nowa 'semiotyka'?"). ${ }^{27}$ More importantly, the author claims that the idea of lesbian poetry and prose as

\footnotetext{
${ }^{23}$ I refer to the distinction between these two types of texts presented by Warkocki, 2014, pp. 263-264.

24 At the same time, Cuber/Tomczok admits that she was not focused on providing a thorough presentation of all Polish texts in which some lesbian motifs can possibly be found (Cuber, 2003, introduction, para. 3).

25 In general, the representation of the lesbian experience tends to be treated as one of the most important features of lesbian literature (cf. Nadana-Sokołowska, 2014a, p. 272).

26 In so doing, she also refers to the features of women's writing as characterized by Ewa Kraskowska.

27 This assumption is probably based on a more general idea that literature itself is constituted solely by two groups of texts - the ones of good artistic value and those that lack such qualities; as a consequence, it is believed that no other categorizations in the field of writing are necessary.
} 
a subgenre of writing supports the image of the works in question as an obscure, undiscovered field of study (the scholar uses the term terra incognita) (Cuber, 2003, section: "Nowa 'semiotyka'?").

The next paper to be mentioned is Bernadetta Darska's 2006 article published in the volume Queerowanie feminizmu. Estetyka, polityka czy coś więcej? [The queering of feminism. Aesthetics, politics or something more?]. In the essay, the terms "lesbian literature/prose" seem to function as transparent and unproblematic, which might be justified by the fact that the scholar focuses on texts created after 1989, i.e., in the period when the word "lesbian" might have been intentionally used as a self-description. Similarly to Cuber/Tomczok, Darska discusses the texts of Schilling, Okoniewska and Mostowik. It is, however, important that when analysing Mostowik's work, she states that only a few texts from the book could be described as lesbian (Darska rightly stresses the fluidity of the characters created by the writer; 2006, p. 198), which suggests that there are some criteria allowing for distinguishing between lesbian and non-lesbian writing. What are they? For Darska, the most important factor seems to be the depiction of the lesbian experience presented as a part of everyday life, thanks to which the works analysed in the presented article gain emancipatory potential (2006, p. 192).

Since the concept of the lesbian experience is mentioned both by Darska and Cuber/Tomczok, the following question could be posed here: what does "the lesbian experience" mean? From both presented articles and our common intuitions it could be concluded that this term is supposed to embrace all experiences - social, psychological, economic, political - which result from being a lesbian. Although it seems clear enough, I would like to complicate this issue and ask: what does it exactly mean to be a lesbian? Where is the border between lesbian and non-lesbian existence? What is the role of the personal and/or social identification? Neither Cuber's/Tomczok's nor Darska's essay answers these questions, which could be justified by the fact that they are not addressed by most of the works analysed by the scholars (Filipiak's/Morska's work would probably serve as an exception). In addition to that, both essays are of a more descriptive nature, since their main aim seems to be to inform the reader about and to mark the existence of Polish prose which in some way refers to female non-heterosexuality. It is, therefore, understandable that Cuber/Tomczok and Darska do not focus on the definition of the term "lesbian." However, as I have already mentioned, this lack is characteristic of the studies which analyse depictions of female homoeroticism in Polish literature. And yet, from the broader theoretical perspective adopted in this paper it would be important to refer to the questions formulated above.

Some interesting and valuable theoretical reflection was provided by Błażej Warkocki in his study Homo niewiadomo. Polska proza wobec odmienności (2007). The author poses the crucial question of how "homosexual literature" can be defined (Warkocki, 2007, p. 37). ${ }^{28} \mathrm{Al}$ though he is reluctant to use any stable, essentialist terms (Warkocki, 2007, p. 24), to which the notion of lesbian literature/writing and authorship may belong, he also claims that for strategic purposes, such names should be used in literary studies and critical texts (Warkocki,

28 Interestingly, Warkocki cites a possible definition of a gay novel that can be found in Michał Witkowski's Lubiewo [Lovetown] (2007, p. 37). Although the scholar writes mostly about homosexual literature in general and not specifically about lesbian works, his analyses obviously comprise women's non-heterosexuality and, therefore, I am also presenting Warkocki's remarks in this paper. 
2007, p. 38). However, at the same time, Warkocki notices that despite the social and political significance of distinguishing various types of "minority" writing as a literary subgenre, the limiting aspect of this gesture also has to be emphasized (2007, p. 196). This is because any identity labels can lead to further marginalization (although on different conditions) of the texts considered to be too particular (e.g., "solely" lesbian or gay) to attract the interest of a wider readership (Warkocki, 2007, p. 196) and therefore not worth a developed, professional discussion. What is important, Warkocki situates his observations in the context of queer theory, represented, for instance, by Judith Butler's and Eve Kosofsky Sedgwick's concepts (2007, pp. 17-44), which renders his remarks about Polish "homosexual literature" (33-42) intentionally provisional.

Similar ideas can be found in Daria Adamowicz's article “"[...] nigdy nie byłam lesbijką' lesbianizm jako nabywanie w polskiej prozie po roku 1989" [I have never been a lesbian lesbianism perceived as acquisition in the Polish prose after 1989] (2008). Although Adamowicz uses the term "lesbian literature" ("literatura lesbijska") and describes its common features (limited to the Polish works published in the period mentioned in the title of the essay, i.e. after 1989, cf. Adamowicz, 2008, p. 83), she proposes understanding lesbianism as an unstable, fluid category achieved by a person/character gradually (pp. 81-82), which, as a consequence, renders the discussed subgenre more open and provisional.

Renata Lis's book entitled Lesbos should also be mentioned here (2017). ${ }^{29}$ I cite this work as an exception, since it is neither an academic nor a critical text - according to the author, it would be best labelled as one of the mixed genres ("gatunek mieszany"), namely a literary essay ("esej literacki"; Lis 2018a, para. 12) ${ }^{30}$ However, since the book itself, as well as Lis's other texts that accompany it, interestingly discuss the subject of this paper, including the meaning and the (im)possibility of applying the terms "(a) lesbian" - I have decided to mention them in my analysis. The leitmotif of Lesbos is found in Sappho's work and biography. ${ }^{31}$ In this context, Lis situates the writings and lives of five other authors from different cultural traditions: Sofia Parnok, Narcyza Żmichowska, Anna Kowalska and Maria Dąbrowska, as well as Jeanette Winterson. In the book, various ways, contexts (with the emphasis on the influence of Sappho) of and demands for depicting love between women in literature are discussed (Lis, 2017, pp. 61, 66, 90-91, 98, 117, 131, 178). Yet, the author distances herself from the terms “(a) lesbian." Whenever used, they are placed in quotation marks (Lis, 2017, pp. 65,

\footnotetext{
${ }^{29}$ I would like to thank Nelly Strehlau, PhD for drawing my attention to this book.

${ }^{30}$ In this context, yet another book should be mentioned, namely Homobiografie. Pisarki i pisarze polscy XIX iXX wieku [Homobiographies. Polish writers of the $19^{\text {th }}$ and $20^{\text {th }}$ century] by Krzysztof Tomasik (2009). The publication analyses a group of biographies of Polish authors in order to reveal their non-heteronormative potential. However, since this is rather an example of popular science and, more importantly, literature is not its main subject, I refer to this source solely marginally. Nevertheless, its significance in the Polish debate about non-heterosexuality remains unquestionable.

${ }^{31}$ Also Iwasiów, in her analyses of the homoerotic motifs in the poetry of Filipiak/Morska and Ewa Sonnenberg, refers to the tradition of Sappho and the island of Lesbos (Iwasiów, 2004, pp. 105-123, 138). In this context, the author uses the terms "sapphic lyric" ("liryka saficzna") or "the authors of the sapphic topic" ("autorki tematu saficznego") (Iwasiów, 2004, p. 110). It is also worth mentioning that Iwasiów herself published a volume of poetry - Miłość [Love, 2001] - in which female homoeroticism plays an important role (cf. Amenta, Kaliściak \& Warkocki, 2021, p. 53). I would like to thank the reviewer for drawing my attention to these publications.
} 
$94,125,131-132,133,173,177)$ which, as she explains in the essays which followed the publication of the analysed book, signalizes her stance in favour of an open and fluid understanding of identity, considered as a broad, multilayered phenomenon, not limited to sexual orientation (Lis, 2018a; 2018b). As a consequence, lesbian literature is also presented solely as the "«lesbian»" one (Lis, 2017, pp. 68, 94). ${ }^{32}$ In addition to that, Lis poses certain esthetical demands for the "«lesbian»" - to use her convention of punctuation - writing, namely she stresses that it should be of high quality and have some artistic value (2017, pp. 131-132, 178). She does not neglect the need for distinguishing special techniques of representing love between women and merely claims that the mentioned subject should be expressed in a sophisticated style, which can enable the "lesbian" texts to obtain the place in the literary canon they deserve (Lis, 2017, pp. 131-132, 178). Sappho's legacy seems to be depicted as a model and source of constant inspiration in the fulfilment of this aim (Lis, 2018a, para. 13).

Given the presented vagueness of the idea of lesbian writing, the following question should be posed: why are some texts described as such? Certainly, the critics' and scholars' interpretations play an important role in popularising such a paradigm of reading (Śmietana, 2007, p. 214). But on what premises are they based? Obviously, it is impossible to answer this question fully here, since we are touching on a subject widely discussed within gay, lesbian and queer studies. However, it would be enough to say that among the factors most commonly enumerated when discussing non-heteronormativity in literature are the poetics of the text (Burzyńska, 2007, pp. 459-460, 463; Ritz, 2002b, pp. 54-55), as well as the author's biography (Kaliściak, 2011, p. 14; Leszkowicz \& Kitliński, 2005, p. 154). In the particular case of lesbian writing in Poland, the first criterion may often seem difficult to apply, given its short tradition and, as a consequence, the scarce number of recognizable strategies of depicting female homoeroticism in Polish literature. In contrast, despite the controversies evoked below (see the next paragraph), the second criterion is often resorted to (as a consequence, many scholars, probably not always intentionally, rely on the rumours relating to the writers' biographies; Sobolczyk, 2015, p. 195, footnote 3; Warkocki, 2013, p. $163^{33}$ ).

The definitional heterogeneity, which does not allow for a teleological narrative about the gradual development of the theoretical consciousness among Polish gender studies and feminist scholars, contributes to the specificity of the Polish discussion about lesbian writing and authorship. A few additional remarks should also be formulated. For instance, it should be noted that the studies of the literary expression of homoeroticism, both male and female, have provoked many controversies among scholars, which included - to refer to Inga Iwasiów's remarks - the reluctance to refer to the biography (2001, p. 440) - both of the writer and of the scholar. At the same time, as I have already mentioned, some Western ideas have been borrowed, even though, as Urszula Śmietana rightly noted, they are not compatible with Polish literature (2007, p. 215). According to the author, while in theoretical texts, the love between women has been commonly described in terms of Johann Jakob Bachofen's concept of ma-

\footnotetext{
${ }^{32}$ In the commentary on this book, Lis explains that Lesbos is about "literature without adjectives" ("literatura bez przymiotników"; 2018a, last para.).

${ }^{33}$ Piotr Sobolczyk and Błażej Warkocki formulated their remarks mostly with reference to male homosexual literature, but, as Nadana-Sokołowska observed, the mechanism seems to be the same in the context of women's writing (Nadana-Sokołowska, 2014a, p. 273; cf. also Warkocki, 2007, pp. 138-139).
} 
triarchy, as well as of Adrienne Rich's lesbian continuum, Polish literary works do not follow this paradigm and depict female (and male) homoeroticism in a different manner (Śmietana, 2007, p. 215). Apart from that, in one of her articles, to which I would like to make a longer reference here, Inga Iwasiów (2001) discusses some problems encountered by scholars (especially Polish ones) who decide to analyse the presence of lesbian themes in contemporary Polish literature. ${ }^{34}$ As one of the difficulties, the author names the lack of trustworthy terminology (the one which exists is, according to the scholar, related to the rejected paradigm most probably the patriarchal one), needed to describe the literary expression of female homoeroticism (Iwasiów, 2001, p. 435). The notions - sometimes literal, sometimes metaphorical - which recur in the analysed article are silence and absence (Iwasiów, 2001, pp. 435, 436, 439-440, 442, 445) - they describe the virtual non-existence or, more optimistically, the tenuous existence of lesbian writing in the contemporary Polish literature (it is, therefore, significant that, even though Iwasiów discusses late $20^{\text {th }}$ century literature, she still feels obliged to stress the minor role of female homoeroticism in Polish writing). Finally, when referring to the work of Ewa Schilling, she suggests that it could be interpreted from the perspective of queer theory, which is capable of embracing and interpreting various types of alterity, including lesbianism (Iwasiów, 2001, p. 450).

I would like to stop at this idea and, in a short digression, consider generalizing it. It is clear that the Polish gender studies discourse and social practices related to it have a complicated history, which shapes their contemporary form. One of its features, often stressed by scholars, is heterogeneity, whose positive sides are more and more often emphasized (this is also the perspective which I would like to embrace in this paper). For instance, Monika Świerkosz (2014, pp. 86-87), as well as Robert Kulpa, Joanna Mizielińska and Agata Stasińska (2012) argue that because of the belated and simultaneous acquisition of various threads of gender and feminist studies discourse, we can learn from the mistakes of Western theoreticians and activists and avoid such traps as an essentialist and separatist view on sexual identity (both hetero- and non-heteronormative; Kulpa et al., 2012, p. 130). As Kulpa, Mizielińska and Stasińska emphasize, the Polish discourse about non-heterosexuality has been co-shaped by the queer perspective from the very beginning, which did not impede the functioning of the gay and lesbian movement but helped to make it more open (2012, pp. 121-125). Would it be possible to adopt a similar point of view in the context of Polish lesbian writing? The aim of this procedure would not be to prove that most of the authors express a queer perspective in their texts, but to show that seeing Polish lesbian literature through the lens of queer theory might allow for interpreting motifs which seem to be the sign of a lack, impossibility and closure as, in fact, a positive, subversive resignation from clear, finished and static projects of identity. To some degree this strategy was adopted by Lis - reluctant as she is to use the term "lesbian" as an identity label. In addition, as Bieńko (2019, p. 87) rightly remarks, this word can also be understood as an open, diverse and inclusive identity category. ${ }^{35}$ Other studies

\footnotetext{
${ }^{34}$ It is also worth stressing that lesbian themes ("wątki lesbijskie") is the exact term used by Iwasiów, who, as it seems, intentionally chose a more descriptive name, rather than expressions such as lesbian literature/writing/prose, etc.

${ }^{35}$ The author refers to Browne and Olasik (2016).
} 
which refer to this perspective are, for instance, the already mentioned interpretations by Warkocki (2007), Adamowicz (2008) and Iwasiów (2001) and, obviously, the anthology Dezorientacje... (Amenta, Kaliściak \& Warkocki, eds., 2021). In the introduction, the authors, when characterising the representations of female homoeroticism in the Polish literature, point to the complexity of this type of writing which goes beyond any stable vision of identity and as such introduces queer non-essentialist dynamics (Amenta, Kaliściak \& Warkocki, 2021, pp. 47-55). Adopting this wide perspective would allow for flexible, productive interpretations of literature and overcoming the binary vision of sexuality as comprising solely homo- and heterosexuality (Amenta, Kaliściak \& Warkocki, 2021, pp. 25-28). This can be noted even on the level of terminology, since instead of writing about "the lesbian tradition" ("tradycja lesbijska"), the editors prefer to use a broader expression: "the sapphic-matrilinear line" ("linia saficko-matrylinearna"). The authors have proved that applying queer lenses in reading Polish literature works well with reference to a large body of publications, including texts which depict various relationships between women. ${ }^{36}$

\section{Conclusion}

In conclusion, it should be noted that the terms lesbian writing/literature, as well as the concept of lesbian authorship, are distinctly present in Polish literary studies. The theoretical reflection upon this subject is still characterized by some lacks and inconsistencies, but, at the same time, these aspects constitute the specificity of the Polish discourse developed in this field. One of the most tempting strategies of conceptualising lesbian writing seems to be a perspective rooted in queer theory, which, however, always has to be applied cautiously; apart from that, as this methodology typically avoids any identity labels, the term "(a) lesbian" would be applied only provisionally or would not be used at all. Therefore, although it may seem obvious, it should be stated that the technique of reading women's non-heterosexuality in Polish literature should always be modified to fit the studied text. However, what is also necessary is sensitivity to the meaning and functioning of the terms used. Lesbian writing/authorship are not neutral words, since they have their history and - sometimes strongly equivocal - connotations. To take all these complications into account would be the main practical postulate formulated in the final part of this paper. It would be difficult to anticipate how the type of literature discussed in this article will continue to develop in Poland. One of the aspects which might be of importance is the vision of identity - essentialist, fluid, in-between? - adopted not only by the authors, but also by the readers who use various interpretative strategies. On the theoretical level, as I have argued above, there is still much to be done, also with reference to the past and therefore, I hope that the analyses presented here will encourage other scholars to continue this discussion.

\footnotetext{
${ }^{36}$ I would like to thank the reviewers for drawing my attention to these issues.
} 


\section{References}

Adamowicz, D. (2008). “[...] nigdy nie byłam lesbijką” - lesbianizm jako nabywanie w polskiej prozie po roku 1989. In M. Dąbrowski (Ed.), Lektury ptci. Polskie (kon)teksty (pp. 81-90). Warszawa: Dom Wydawniczy Elipsa.

Amenta A., Kaliściak T., \& Warkocki B. (2021). Literatura przewrotna. In A. Amenta, T. Kaliściak, \& B. Warkocki (Eds.), Dezorientacje. Antologia polskiej literatury queer (pp. 19-76). Warszawa: Wydawnictwo Krytyki Politycznej.

Amenta A., Kaliściak T., \& Warkocki B. (Eds.). (2021). Dezorientacje. Antologia polskiej literatury queer (2021). Warszawa: Wydawnictwo Krytyki Politycznej.

Biedroń, R. (2010). Historia homoseksualności w Polsce. In J. Kochanowski, M. Abramowicz \& R. Biedroń (Eds.), Queer studies. Podręcznik kursu (pp. 57-95). Warszawa: Kampania Przeciw Homofobii.

Bieńko, M. (2019). "Pedał" i "lesba" jako społeczne pojęcia życia codziennego. Heteroseksualne uprzedzenia językowe dotyczące gejów i lesbijek. InterAlia 14, 86-102.

Bonnet, M.-J. (1997). Związki miłosne między kobietami od XVI do XX wieku (B. Szwarcman-Czarnota, Trans). Warszawa: Sic!

Borkowska, G. (1996). Cudzoziemki. Studia o polskiej prozie kobiecej. Warszawa: IBL Wydawnictwo.

Borkowska, G. (1998). Historia wypadków miłosnych. In I. Iwasiów \& P. Urbański (Eds.), Pogranicza wrażliwości w literaturze dawnej oraz współczesnej. Część I. Miłość (pp. 21-29). Szczecin: Wydawnictwo Naukowe Uniwersytetu Szczecińskiego.

Browne, K., \& Olasik, M. (2016). Feminism, Lesbian. In N.A. Naples (Ed.), The Willey-Blackwell Encyclopedia of Gender and Sexuality Studies. London: Blackwell.

Brückner, A. (1927). Słownik etymologiczny języka polskiego. Kraków: Krakowska Spółka Wydawnicza.

Burzyńska, A. (2007). Gender i queer. In A. Burzyńska \& M. P. Markowski (Eds.), Teorie literatury XX wieku. Podręcznik (pp. 439-473). Kraków: Znak.

Chudoba, E. (2012). Literatura i homoseksualność. Zarys problematyki genderowej w kanonicznych tekstach literatury polskiej i światowej. Kraków: Wydawnictwo Libron -Filip Lohner.

Cuber, M. (2003). Les-silent story. Retrieved January 7, 2021, from https://kobietykobietom.com/muzyka/art.php?art=203

Cuber, M. (2012). Lot koszący? Perspektywy najnowszej homoerotycznej literatury popularnej. In A. Gemra \& H. Kubicka (Eds.), Związi i rozwiązki. Relacje kultury i literatury popularnej ze starymi i nowymi mediami (pp. 73-80). Wrocław: Pracownia Literatury i Kultury Popularnej oraz Nowych Mediów.

Darska, B. (2006). Podobieństwa i różnice, czyli literacki świat lesbijki. Przypadek Ewy S., Moniki M. i Magdaleny O. In J. Zakrzewska (Ed.), Queerowanie feminizmu: Estetyka, polityka, czy coś więcej (pp. 191-205). Poznań: Stowarzyszenie Kobiet „Konsola.” 
Donoghue, E. (1993). Passions between women: British lesbian culture 1668-2001. London: Scarlet Press.

Dyszak, A.S. (2014). Nazwy nieheteroseksualnych kobiet we współczesnej polszczyźnie standardowej i potocznej. In J. Wawrzyńczyk (Ed.), Speculum Linguisticum (Vol. 2) (pp. 45-60). Warszawa: BEL Studio.

Faderman, L. (1995). What is lesbian literature? Forming a historical canon. In G.E. Haggerty \& B. Zimmerman (Eds.), Professions of desire: Lesbian and gay studies in literature (pp. 49-59). New York: Modern Language Association of America.

Filipiak, I. (2006). Obszary odmienności. Rzecz o Marii Komornickiej. Gdańsk: Słowo/Obraz Terytoria.

Fish, S. (1999). Professional correctness: Literary studies and political change. Cambridge, MA: Harvard University Press.

Gajewska, A. (2014). Lesbianizm. In M. Rudaś-Grodzka, K. Nadana-Sokołowska, A. Mrozik, K. Szczuka, K. Czeczot, B. Smoleń, A. Nasiłowska, E. Serafin, \& A. Wróbel (Eds.), Encyklopedia gender. Pteć w kulturze (pp. 256-259). Warszawa: Wydawnictwo Czarna Owca.

Gowing, L. (2009). Lesbijki we wczesnonowożytnej Europie, 1500-1800. In R. Aldrich (Ed.) (P. Nowakowski, Ed. \& Trans.), Geje i lesbijki. Życie i kultura (pp. 125-143). Kraków: Universitas.

"InterAlia" 2019, no. 14.

Iwasiów, I. (2001). Obcość kultury, znajoma bliskość innych. Wątki lesbijskie we współczesnej literaturze polskiej. In M. Hornung, M. Jędrzejczak, \& T. Korsak (Eds.), Ciało, pleć, literatura. Prace ofiarowane Profesorowi Germanowi Ritzowi w pięćdziesiąa rocznicę urodzin (pp. 435453). Warszawa: Wiedza Powszechna.

Iwasiów, I. (2004). Jaka to planeta? In I. Iwasiów, Parafrazy i reinterpretacje. Wykłady z teorii i praktyki czytania (pp. 107-138). Szczecin: Wydawnictwo Naukowe Uniwersytetu Szczecińskiego.

Iwasiów, I. (2008). Kobiety na krawędzi dyskursu emancypacyjnego - Monika Mostowik, Grażyna Plebanek, Anna Piwkowska. In M. Dąbrowski (Ed.), Lektury ptci. Polskie (kon)teksty (pp. 6980). Warszawa: Dom Wydawniczy Elipsa.

Jay, K. (1995). Lesbian modernism: (Trans)forming the (c)anon. In G. E. Haggerty \& B. Zimmerman (Eds.), Professions of desire: Lesbian and gay studies in literature (pp. 72-83). New York: Modern Language Association of America.

Kaliściak, T. (2011). Katastrofy odmieńców. Katowice: Wydawnictwo Uniwersytetu Śląskiego.

Karłowicz, J., Kryński A., Niedźwiedzki W. (1952 [1902, 1919]). Słownik języka polskiego. Vol. 2, 7. Warszawa: Państwowy Instytut Wydawniczy.

Kłosińska, K. (2010). Feministyczna krytyka literacka. Katowice: Wydawnictwo Uniwersytetu Śląskiego.

Kraskowska, E. (2003). Piórem niewieścim. Z problemów prozy kobiecej dwudziestolecia międzywojennego. Poznań: Wydawnictwo Naukowe UAM. 
Krzyszpień, J. (2010). Język i emancypacja LGBT: uwagi praktyczne. In J. Kochanowski, M. Abramowicz, \& R. Biedroń (Eds.), Queer studies. Podręcznik kursu (pp. 139-146). Warszawa: Kampania Przeciw Homofobii.

Kulpa, R., Mizielińska, J., \& Stasińska, A. (2012). (Un)translatable queer?, or what is lost and can be found in translation... In S. Mesquita, M.K. Wiedlack, \& K. Lasthofer (Eds.), IMPORT EXPORT - TRANSPORT: Queer theory, queer critique and activism in motion (pp. 115-145). Vienna: Zaglossus.

Leszkowicz, P., \& Kitliński, T. (2005). Miłość i demokracja. Rozważania o kwestii homoseksualnej $w$ Polsce. Kraków: Aureus.

Lewinson, J. (1999). Stownik seksualizmów polskich. Warszawa: Książka i Wiedza.

Linde, M. S. B. (1808). Stownik języka polskiego. Vol. 2, 2nd part. Warszawa: u autora.

Lis, R. (2017). Lesbos. Warszawa: Wydawnictwo Sic!

Lis, R. (2018a). Lesbos - poza polityką tożsamości. Mały Format, 11. Retrieved January 7, 2021, from http://malyformat.com/2018/11/lesbos-poza-polityka-tozsamosci/

Lis, R. (2018b). Lesbijka w cudzysłowie. Dwutygodnik 230. Retrieved January 7, 2021, from https://www.dwutygodnik.com/artykul/7638-lesbijka-w-cudzyslowie.html/

Mizielińska, J. (2006). Płeć, ciało, seksualność. Odfeminizmu do teorii queer. Kraków: Universitas.

Nadana-Sokołowska, K. (2014a). Literatura lesbijska. In M. Rudaś-Grodzka, K. Nadana-Sokołowska, A. Mrozik, K. Szczuka, K. Czeczot, B. Smoleń, A. Nasiłowska, E. Serafin, \& A. Wróbel (Eds.), Encyklopedia gender. Pteć w kulturze (pp. 270-274). Warszawa: Wydawnictwo Czarna Owca.

Nadana-Sokołowska, K. (2014b). Związki kobiet. In M. Rudaś-Grodzka, K. Nadana-Sokołowska, A. Mrozik, K. Szczuka, K. Czeczot, B. Smoleń, A. Nasiłowska, E. Serafin, \& A. Wróbel (Eds.), Encyklopedia gender. Pleć w kulturze (pp. 596-599). Warszawa: Wydawnictwo Czarna Owca.

Nastulczyk, T., \& Oczko P. (2012). Homoseksualność staropolska. Przyczynek do badań. Kraków: Collegium Columbinum.

Norton, R. (2002). The "Sodomite" and the "Lesbian." In Rictor Norton, A critique of social constructionism and postmodern queer theory. Retrieved June 19, 2021, from http://rictornorton.co.uk/social22.htm\#lesbian

Nowak, T.Ł. (2020). Język ukrycia. Zapisany socjolekt gejów. Kraków: Universitas.

Ritz, G. (1998). Niewypowiadalne pożądanie a poetyka narracji (A. Kopacki, Trans.). In W. Bolecki \& E. Kuźma (Eds.), Literatura wobec niewyrażalnego (pp. 131-143). Warszawa: IBL PAN.

Ritz, G. (2002a). Nić w labiryncie pożądania. Gender i pleć w literaturze polskiej od romantyzmu do postmodernizmu (B. Drąg, A. Kopacki \& M. Łukasiewicz, Trans.). Warszawa: Wiedza Powszechna.

Ritz, G. (2002b). Literatura w labiryncie pożądania. Homoseksualność a literatura polska (A. Kopacki, Trans.). In G. Ritz. Nić w labiryncie pożądania. Gender i pleć w literaturze polskiej od romantyzmu do postmodernizmu (B. Drąg, A. Kopacki, M. Łukasiewicz, Trans.) (pp. 52-63). Warszawa: Wiedza Powszechna. 
Rodzoch-Malek, J. (2012). W jaki sposób mówi się w polszczyźnie o homoseksualizmie i osobach homoseksualnych? Analiza leksyki na podstawie danych leksykograficznych i tekstowych [Unpublished doctoral dissertation] from http://depotuw.ceon.pl/handle/item/204 (7.01.2021). Warszawa: University of Warsaw.

Stownik języka polskiego (1962). Vol. 4. (W. Doroszewski, Ed.). Warszawa: Wiedza Powszechna.

Śmieja, W. (2010). Literatura, której nie ma. Szkice o polskiej “literaturze homoseksualnej.” Kraków: Universitas.

Śmieja, W. (2015). Homoseksualność i polska nowoczesność. Katowice: Wydawnictwo Uniwersytetu Śląskiego.

Śmietana, U. (2007). Lektury inności. In M. Dąbrowski \& R. Pruszczyński (Eds.), Lektury inności. Antologia (pp. 214-224). Warszawa: Dom Wydawniczy Elipsa.

Sobolczyk, P. (2015). Queerowe subwersje. Polska literatura homotekstualna i zmiana spoteczna. Warszawa: IBL PAN.

Świerkosz, M. (2014). W przestrzeniach tradycji. Proza Izabeli Filipiak i Olgi Tokarczuk w sporach o literature, kanon i feminizm. Warszawa: IBL PAN Wydawnictwo, Stowarzyszenie Pro Cultura.

Tomasik, K. (2009). Homobiografie. Pisarki i pisarze polscy XIX i XX wieku. Warszawa: Wydawnictwo Krytyki Politycznej.

Walczewska, S. (2000). Damy, rycerze i feministki. Kobiecy dyskurs emancypacyjny w Polsce. Kraków: Wydawnictwo eFKa.

Warkocki, B. (2007). Homo niewiadomo. Polska proza wobec odmienności. Warszawa 2007: Wydawnictwo Sic!

Warkocki, B. (2013). Różowy język. Literatura i polityka kultury na początku wieku. Warszawa: Wydawnictwo Krytyki Politycznej.

Warkocki, B. (2014). Literatura homoseksualna (męska). In M. Rudaś-Grodzka, K. Nadana-Sokołowska, A. Mrozik, K. Szczuka, K. Czeczot, B. Smoleń, A. Nasiłowska, E. Serafin, \& A. Wróbel (Eds.), Encyklopedia gender. Pteć w kulturze (pp. 263-265). Warszawa: Wydawnictwo Czarna Owca.

Katarzyna Lisowska, PhD, works in the Department of Polish Studies at the University of Wrocław. In her research, she focuses on gender studies discourse in Polish literary studies. She is also interested in the cultural representations of eating disorders, old age, asexuality and anarchism. 